\title{
High miR-3687 Expression Affects Migratory and Invasive Ability of Oesophageal Carcinoma
}

\author{
KOTARO HAGIO $^{1}$, SHINJI FURUYA ${ }^{1}$, JIRO NAKAMURA ${ }^{2}$, SUGURU MARUYAMA ${ }^{1}$, \\ KENSUKE SHIRAISHI ${ }^{1}$, HIROKI SHIMIZU ${ }^{1}$, HIDENORI AKAIKE ${ }^{1}$, NAOHIRO HOSOMURA ${ }^{1}$, \\ YOSHIHIKO KAWAGUCHI ${ }^{1}$, HIDETAKE AMEMIYA ${ }^{1}$, HIROMICHI KAWAIDA ${ }^{1}$, \\ MAKOTO SUDO $^{1}$, SHINGO INOUE ${ }^{1}$, HIROSHI KONO ${ }^{1}$ and DAISUKE ICHIKAWA ${ }^{1}$ \\ ${ }^{1}$ First Department of Surgery, Faculty of Medicine University of Yamanashi, Yamanashi, Japan; \\ ${ }^{2}$ Department of General Surgery, Karuizawa Hospital, Nagano, Japan
}

\begin{abstract}
Background/Aim: Basaloid squamous cell carcinoma of the oesophagus (BSCCE) is a variant of oesophageal squamous cell carcinoma (ESCC), that has a more aggressive biological behaviour than that of typical ESCC. miR3687 has been previously identified to be highly expressed in BSCCE. This study aimed to evaluate the prognostic impact of miR-3687 in ESCC and determine the role of miR-3687 in ESCC motility. Materials and Methods: miR-3687 expression in human ESCC cell lines and in primary tumour samples obtained from patients with ESCC who underwent esophagectomy were analyzed via real-time polymerase chain reaction $(P C R)$. Knockdown and over-expression experiments were conducted with miR-3687 siRNA and miRNA mimic, and the effect on cell proliferation, migration, and invasion was analyzed. Results: A total of 92 samples were analyzed. High miR-3687 expression was correlated with poor prognosis. miR3687 upregulation promoted cell migration and invasion. Conclusion: miR-3687 expression negatively impacts the prognosis of patients with ESCC.
\end{abstract}

Oesophageal cancer is one of the primary malignant tumours with poor prognosis, and its morbidity and mortality rank eighth and sixth worldwide, respectively, among malignant tumours (1). Unlike other organs, the oesophagus has no serous membrane and thus the tumour easily invades other organs. Moreover, the location of the oesophagus makes it adjacent to

This article is freely accessible online.

Correspondence to: Shinji Furuya, First Department of Surgery, Faculty of Medicine, University of Yamanashi, 1110 Shimokato, Chuo, Yamanashi 409-3898, Japan. Tel/Fax: +81 552737390, e-mail: sfuruya@yamanashi.ac.jp

Key Words: microRNA, basaloid squamous cell carcinoma, oesophageal cancer, miR-3687. large blood vessels and lymph nodes, the lungs, heart, and stomach. As such, the tumour can not only migrate to nearby organs, but also to distant organs such as the brain and adrenal gland. Given that oesophageal carcinoma is often asymptomatic or presents with non-specific symptoms, patients are usually diagnosed at the late stage of the disease. Therefore, accurate diagnostic modalities and effective treatment targets need to be identified to improve the prognosis of oesophageal carcinoma.

Basaloid squamous cell carcinoma of the oesophagus (BSCCE) was first identified 20 years ago as a variant of squamous cell carcinoma with a distinct basaloid morphology $(2,3)$. It commonly develops in the mid to distal oesophagus and among elderly men. The incidence of BSCCE accounts for approximately $1 \%$ of all cases of oesophageal squamous cell carcinoma (ESCC). Histologically, it is characterised by a solid growth pattern with a nesting, lobular, or trabecular arrangement of basaloid cells; small cystic spaces; and foci of comedo-type necrosis in central areas of the tumour (4). Several studies have shown that BSCCE has relatively undifferentiated features and undeveloped cell organelles and its biological behaviour is more aggressive than that of typical $\operatorname{ESCC}(2,5,6)$. Furthermore, it is reported that BSCCE and ESCC retain different cellular phenotypes with distinct genetic and epigenetic alterations (7). Therefore, analysing the characteristics of BSCCE is important in improving the prognosis of oesophageal cancer.

MicroRNA (miRNA) is a single-stranded RNA molecule measuring 21-25 bases in length that is involved in the regulation of post-transcriptional expression of genes in eukaryotes. miRNA binds to multiple, partially complementary sites of the 3 'UTR of target genes, destabilizing the target mRNA, and suppressing translation and protein production (8). miRNA mediated transcriptional repression plays an important role in various biological processes such as development, cell proliferation and differentiation, apoptosis, and metabolism (912). MiRNAs also play an important role in cancer. Previous studies have reported that miRNA expression is altered in various cancers, linking miRNA expression to either initiation 
Table I. Summary of 17 esophageal squamous cell carcinoma cell lines.

\begin{tabular}{lccc}
\hline Cell line & Age (years) & Gender & Differentiation \\
\hline TE1 & 58 & Male & Well differentiated squamous carcinoma \\
TE4 & 48 & Female & Well differentiated squamous carcinoma \\
TE5 & 73 & Female & Poorly differentiated squamous carcinoma \\
TE6 & Male & Well differentiated squamous carcinoma \\
TE8 & 61 & Male & Moderately differentiated squamous carcinoma \\
TE11 & Male & Moderately differentiated squamous carcinoma \\
TE13 & 58 & Male & Poorly differentiated squamous carcinoma \\
TE14 & 65 & Male & Moderately differentiated squamous cell carcinoma \\
TE15 & 57 & Female & Well differentiated squamous carcinoma \\
KYSE30 & Male & Well differentiated squamous cell carcinoma. \\
KYSE50 & 58 & Male & Poorly differentiated human squamous cell carcinoma \\
KYSE70 & 64 & Male & Poorly differentiated human squamous cell carcinoma \\
KYSE110 & 58 & Male & Poorly differentiated squamous carcinoma cell carcinoma \\
KYSE150 & Female & Poorly differentiated squamous carcinoma cell carcinoma \\
KYSE170 & 67 & Female & Moderately differentiated squamous cell carcinoma \\
KYSE790 & 63 & Well differentiated squamous cell carcinoma \\
KYSE890 & 49 & Male & Moderately differentiated squamous cell carcinoma \\
\hline
\end{tabular}

or progression of cancer (13-17). Variation of miRNA expression affects the characteristics of carcinoma by regulating the expression of oncogenes or tumour suppressors (12). Therefore, miRNAs may serve as biomarkers for cancer diagnosis, prognosis, and pathogenesis (18).

In this study, we aimed to investigate the impact of miR3687 on the prognosis of ESCC.

\section{Materials and Methods}

Patients and ethical concerns. ESCC tumour samples were obtained from patients with histologically-proven primary ESCC who underwent esophagectomy at the Yamanashi University Hospital (Yamanashi, Japan) between 2004 and 2012. The eligibility criteria were as follows: no synchronous or metachronous cancers (in addition to ESCC) and no preoperative chemotherapy or radiation therapy. Patients with non-curative resected tumours were excluded. Relevant clinicopathological and survival data were obtained from the hospital database. Staging was according to the International Union Against Cancer (UICC)/TNM Classification of Malignant Tumors (7th edition) (19).

In our previous analysis, 4 miRNAs were identified to be highly expressed in BSCCE tissues, namely, miR-200c-3p, miR-205-5p, miR-3687, and miR-4732-5p. Patients with ESCC were divided into two groups, those with low miR-3687 expression $[<7.9$ (relative expression to normal tissue)] and those with high expression $(\geq 7.9)$ by the top 10 percentile.

Written informed consent for use of samples and data were obtained from all patients. This study was approved by the Ethics Committee of Yamanashi University (approval number: 1888).

\section{Sample collection}

Formalin-fixed paraffin-embedded tissue specimens. The formalinfixed paraffin-embedded (FFPE) samples of ESCC were collected from Yamanashi University Hospital. Total RNA was extracted from
5- $\mu \mathrm{m}$ thick FFPE using the RNeasy FFPE Kit (Qiagen, Hilden, Germany) according to the manufacturer's instructions.

Cell lines. Human ESCC cell lines TE13 and TE14 were obtained from the Cell Resource Center for Biomedical Research Institute of Development, Aging, and Cancer (Tohoku University, Sendai, Japan) (20). The human ESCC cell lines KYSE30 and KYSE150 were obtained from the Japanese Collection of Research Bioresources Cell Bank (21). These cells were grown in RPMI-1640 medium (NacalaiTesque, Kyoto, Japan) supplemented with $100 \mathrm{U} / \mathrm{ml}$ of penicillin, $100 \mu \mathrm{g} / \mathrm{ml}$ of streptomycin, and $10 \% \mathrm{FBS}$. The cells were cultured in dishes in a humidified incubator at $37^{\circ} \mathrm{C}$ and $5 \% \mathrm{CO}_{2}$ in air.

RNA extraction, reverse transcription, and RT-qPCR. Total RNA was extracted using TRIzol Reagent (Invitrogen: Thermo Fisher Scientific, Inc.), and refined using the RNeasy Mini Kit (Qiagen, Hilden, Germany). RNA concentration was measured using a NanoDrop 2000/2000c (Thermo Fisher Scientific, Inc.). cDNAs were synthesized using the TaqMan miRNA Reverse Transcription Kit (Applied Biosystems, Tokyo, Japan) based on the specific stemloop RT primer design. Reverse transcriptase reaction contained 10 ng RNA samples. We used $3 \mu$ of stem-loop primers (hsa-miR3687, Assay ID: 464645 mat), $1.5 \mu \mathrm{l}$ of $10 \times \mathrm{RT}$ buffer, $0.15 \mu \mathrm{l}$ of $100 \mathrm{mM}$ dNTPs, $1 \mu \mathrm{l}$ of MultiScribe reverse transcriptase, $0.19 \mu \mathrm{l}$ of RNase inhibitor and $4.16 \mu \mathrm{l}$ of nuclease free water in a final volume of $15 \mu \mathrm{l}$. The reaction mixtures were incubated for $30 \mathrm{~min}$ at $16^{\circ} \mathrm{C}, 30 \mathrm{~min}$ at $42^{\circ} \mathrm{C}, 5 \mathrm{~min}$ at $85^{\circ} \mathrm{C}$, and then held at $4^{\circ} \mathrm{C}$. Next, $1.33 \mu \mathrm{l}$ of cDNA was amplified using $10 \mu \mathrm{l}$ of $2 \times$ TaqMan Universal PCR master mix, $1 \mu$ of primers and probes, and $7.67 \mu l$ of nuclease free water in a final volume of $20 \mu \mathrm{l}$. The initial PCR step was a $10 \mathrm{~min}$ hold at $95^{\circ} \mathrm{C}$ followed by $1 \mathrm{~min}$ of annealing/extension at $63^{\circ} \mathrm{C}$. The PCR reactions were run on a 7500 Real-Time PCR machine (Applied Biosystems) and analysed using the 7500 System SDS software. miRNA expression was normalised against the expression of U6 small nuclear RNA (RNU6B) and analysed via the $2-\Delta \Delta \mathrm{Cq}$ method. 

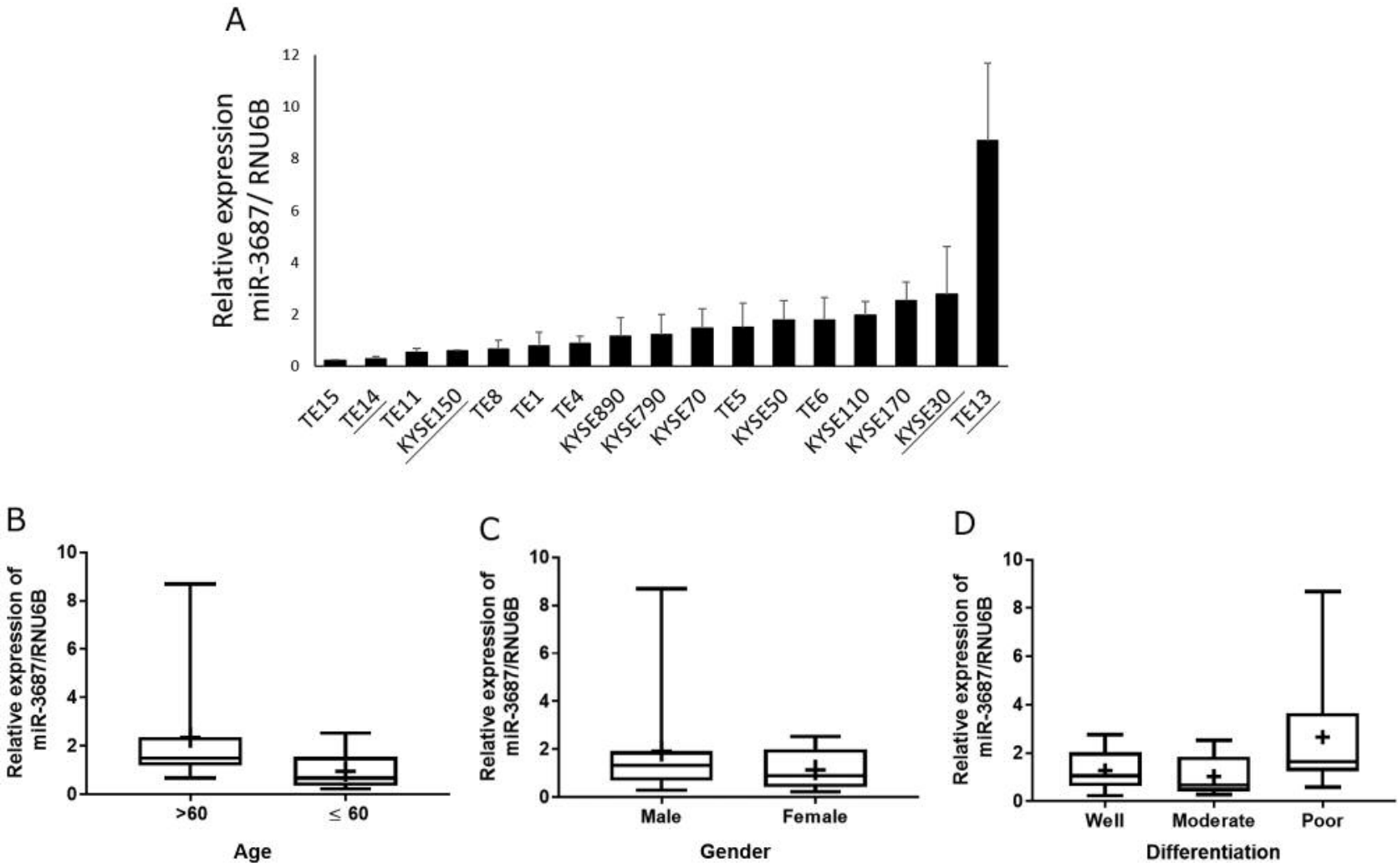

Figure 1. Relationships between clinicopathological features of ESCC cell lines and expression of miR-3687. (A) The expression of miR-3687 in ESCC cell lines. The underlined cell lines were chosen for the assay. Relationships between age $(B)$, sex $(C)$ and differentiation $(D)$ and expression of miR-3687 in ECSS cell lines are shown. ESCC: Oesophageal squamous cell carcinoma.

Cell transfection. Cells were plated $\left(2 \times 10^{5 / \text { well }) ~ i n ~ a ~ 6-w e l l ~ p l a t e ~}\right.$ $24 \mathrm{~h}$ prior to transfection. For downregulating miR-3687, the miR3687 inhibitor (mirVana miRNA Inhibitor, Anti-miR ID: MH20273) or negative control inhibitor miRNA (mirVana miRNA Inhibitor Negative Control \#1) was used to transfect the ESCC cells. For miR-3687 overexpression, the miR-3687 mimic (mirVana miRNA Mimic, Pre-miR ID: MC20273) or negative control mimic miRNA (mirVana miRNA Mimic Negative Control \#1) was used.

For the preparation of transfection reagents, 90 pmol of mimic or inhibitor were diluted in Opti-MEM media (Gibco; Thermo Fisher Scientific, Inc.) and mixed with $7 \mu \mathrm{l}$ of Lipofectamine RNAiMAX Reagent (Invitrogen Life Technologies) diluted in Opti-MEM. After incubating the cells for $24 \mathrm{~h}$, several assays were performed.

Cell proliferation assay. To measure cell growth rate, the number of viable cells at various time points after transfection was assessed via the colorimetric water-soluble tetrazolium salt assay (Cell Counting Kit 8; Dojindo Laboratories, Kumamoto, Japan). According to the manufacturer's protocol, cells transfected with miRNA mimics or inhibitor were plated in 96-well plates. Ten $\mu 1$ cell counting assay kit- 8 solution were added to each well and the absorbance was measured at $450 \mathrm{~nm}$ using a microplate reader.

Analysis of cell migration and invasion. The migration assay was conducted using a Cell Culture Insert with a pore size of $8 \mu \mathrm{m}$ (BD
Biosciences). Biocoat Matrigel (BD Biosciences) was used to evaluate cell invasion potential. Briefly, cells $\left(1.0 \times 10^{5}\right.$ cells per well) were seeded in the upper chamber in serum-free medium $24 \mathrm{~h}$ after transfection. $10 \%$ FBS and medium were added to the lower chamber. The chambers were incubated at $37^{\circ} \mathrm{C}$ for $24 \mathrm{~h}$ in $5 \% \mathrm{CO}_{2}$, and nonmigrated or non-invaded cells were then removed from the upper side of the membrane by scrubbing with cotton swabs. Meanwhile, migrated or invaded cells were fixed on the membrane and stained with Diff-Quick staining reagents (Sysmex, Kobe, Japan). The migrated or invaded cells on the lower side of the membrane were counted in 10 independent fields of view at $100 \times$ magnification for each insert. Each assay was performed in triplicate.

Statistical analysis. The Mann-Whitney $U$-test and the $t$-test for unpaired data were performed for comparing sample data. The Chisquare test or Fisher's exact probability test was used to evaluate correlations between the miRNA levels and clinicopathological factors. For the survival rate analysis, Kaplan-Meier survival curves were constructed for groups based on univariate predictors, and differences between the groups were analysed with the log-rank test or the Wilcoxon test. Univariate and multivariate survival analyses were performed using the likelihood ratio test of the stratified Cox proportional hazards model. For all analyses, a $p$-value of $<0.05$ was considered statistically significant using GraphPad Prism ${ }^{\circledR}$ version 7 (GraphPad Software, San Diego, CA, USA). 
A

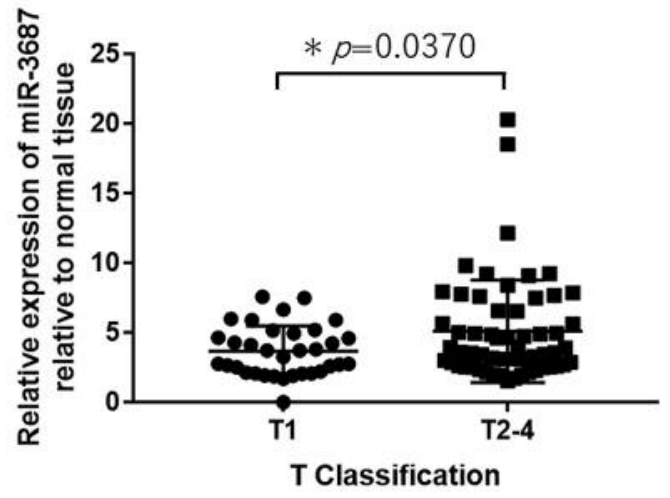

B

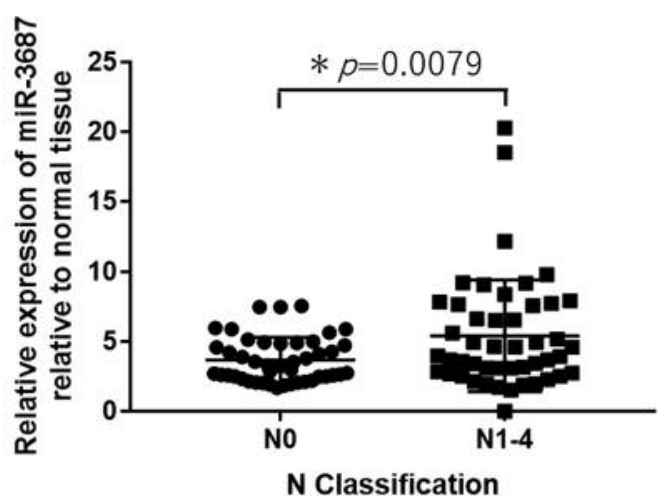

C

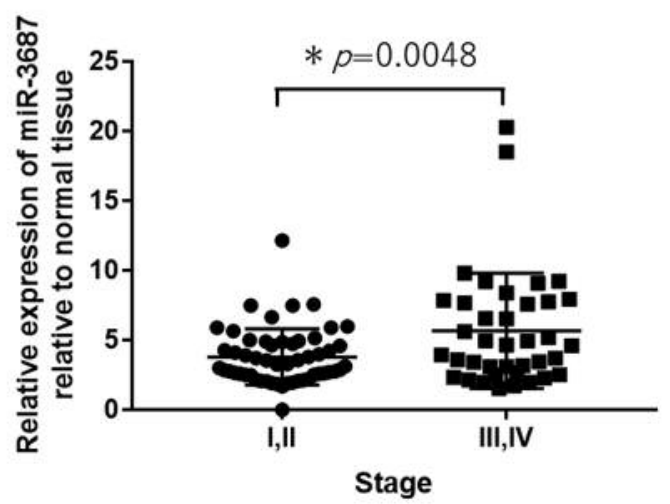

Figure 2. Relative expression of miR-3687 in 92 ESCC tissues at different TNM stages. (A) Expression of miR-3687 at different $T$ Classifications: T1 and T2-4. (B) Expression of miR-3687 at different $N$ Classifications: NO and N1-4. (C) Expression of miR-3687 at different Stages: I, II and III, IV. ESCC: Oesophageal squamous cell carcinoma.

\section{Results}

miR-3687 expression in ESCC cell lines. ESCC tumour samples were obtained from 92 patients. We first evaluated the expression of miR-3687 in ESCC cell lines (Table I). Although all the cell lines used were ESCC, different values were observed. miR-3687 was highly expressed in KYSE30
Table II. Relationships between clinicopathological features of ESCC and the expression of $m i R-3687$.

\begin{tabular}{|c|c|c|c|c|}
\hline \multirow[t]{2}{*}{ Factors } & \multirow[t]{2}{*}{ Patients } & \multicolumn{2}{|c|}{ miR-3687 } & \multirow[t]{2}{*}{$p$-Value } \\
\hline & & Low & High & \\
\hline \multicolumn{5}{|l|}{ Gender } \\
\hline Male & 80 & 72 & 8 & 1 \\
\hline Female & 12 & 11 & 1 & \\
\hline \multicolumn{5}{|l|}{ Age } \\
\hline$\leq 65$ & 34 & 31 & 3 & 1 \\
\hline$>65$ & 58 & 52 & 6 & \\
\hline \multicolumn{5}{|l|}{ Smoking } \\
\hline No & 15 & 13 & 2 & 0.637 \\
\hline Yes & 77 & 70 & 7 & \\
\hline \multicolumn{5}{|l|}{ Tumor size(mm) } \\
\hline$\leq 4$ & 42 & 40 & 2 & 0.173 \\
\hline$>4$ & 50 & 43 & 7 & \\
\hline \multicolumn{5}{|l|}{ Differentiation } \\
\hline Well & 25 & 21 & 4 & 0.514 \\
\hline Moderate & 49 & 45 & 4 & \\
\hline Poor & 18 & 17 & 1 & \\
\hline \multicolumn{5}{|l|}{ Lymphatic invasion } \\
\hline Absent & 34 & 34 & 0 & $0.024 *$ \\
\hline Present & 58 & 49 & 9 & \\
\hline \multicolumn{5}{|l|}{ Venous invasion } \\
\hline Absent & 36 & 34 & 2 & 0.474 \\
\hline Present & 56 & 49 & 7 & \\
\hline \multicolumn{5}{|l|}{$\mathrm{T}$ Classification } \\
\hline $\mathrm{T} 1$ & 34 & 34 & 0 & $0.024 *$ \\
\hline $\mathrm{T} 2-4$ & 58 & 49 & 9 & \\
\hline \multicolumn{5}{|l|}{ N Classification } \\
\hline No & 45 & 45 & 0 & $0.003^{*}$ \\
\hline N1-4 & 47 & 38 & 9 & \\
\hline \multicolumn{5}{|l|}{ TNM Stage } \\
\hline I, II & 54 & 53 & 1 & $0.003^{*}$ \\
\hline III, IV & 38 & 30 & 8 & \\
\hline \multicolumn{5}{|l|}{ Recurrence form } \\
\hline Local & 3 & 1 & 2 & 0.163 \\
\hline Lymph node & 18 & 16 & 2 & \\
\hline Distant metastasis & 8 & 7 & 1 & \\
\hline Dissemination & 1 & 1 & 0 & \\
\hline Multiple & 6 & 6 & 0 & \\
\hline
\end{tabular}

${ }^{*} p<0.05$ : Fisher's exact test. ESCC: Oesophageal squamous cell carcinoma.

and TE13 cells, while it had low expression in KYSE150 and TE14 cells (Figure 1A). Analysis of the association between miR-3687 expression and the characteristics of each cell line showed no significant difference regarding age, sex, and differentiation (Figure 1B, C, and D). This indicates that the histological features of ESCC were not related to miR3687 expression in these cell lines.

Relationships between miR-3687 expression and clinicopathological features of ESCC. miR-3687 expression in the 92 ESCC tissues was then correlated with clinico- 
Table III. The 5-year survival rate of patients with ESCC according to various clinicopathological parameters.

\begin{tabular}{|c|c|c|}
\hline & 5 year-overall survival rate $(\%)$ & $p$-Value \\
\hline \multicolumn{3}{|l|}{ Gender } \\
\hline Male & 66.7 & \\
\hline Female & 49.9 & 0.265 \\
\hline \multicolumn{3}{|l|}{ Age } \\
\hline$\leq 65$ & 49.7 & \\
\hline$>65$ & 53.4 & 0.863 \\
\hline \multicolumn{3}{|l|}{ Differentiation } \\
\hline Well-/moderate & 52.6 & \\
\hline Poor & 50 & 0.501 \\
\hline \multicolumn{3}{|l|}{ Lymphatic invasion } \\
\hline Absent & 73.4 & \\
\hline Present & 39.7 & $0.0023 *$ \\
\hline \multicolumn{3}{|l|}{ Venous invasion } \\
\hline Absent & 66.6 & \\
\hline Present & 42.9 & $0.0369 *$ \\
\hline \multicolumn{3}{|l|}{ T Classification } \\
\hline $\mathrm{T} 1$ & 82.4 & \\
\hline $\mathrm{T} 2-4$ & 34.5 & $0.0000391^{*}$ \\
\hline \multicolumn{3}{|l|}{ N Classification } \\
\hline No & 71 & \\
\hline N1-4 & 34 & $0.000384 *$ \\
\hline \multicolumn{3}{|l|}{$\operatorname{miR}-3687$} \\
\hline Low & 59.9 & \\
\hline High & 40.5 & $0.0365^{*}$ \\
\hline
\end{tabular}

$* p<0.05$ : Log-rank test. ESCC: Oesophageal squamous cell carcinoma

pathological features, such as $\mathrm{T}$ and $\mathrm{N}$ classification and stage. High miR-3687 expression was associated with $\mathrm{T}$ and $\mathrm{N}$ classifications and stage (Figure 2A, B, C). Meanwhile, similar to the results from cell lines, miR-3687 expression was also not associated with histological differentiation.

The miR-3687 low-expression group and the miR-3687 high-expression group comprised 83 and 9 patients, respectively. miR-3687 expression was associated with lymphatic invasion, $\mathrm{T}$ classification, $\mathrm{N}$ classification, and stage (Table II). This result indicates that high miR-3687 expression in BSCCE is related to the clinicopathological features of the malignancy, including tumour development and lymph node metastasis.

Effect of miR-3687 expression on the survival of patients with ESCC. We compared the 5-year overall survival (OS) of patients with ESCC with various clinicopathological features and miR-3687 expression (Table III). Similar with lymphatic invasion, venous invasion, $\mathrm{T}$ classification, and $\mathrm{N}$ classification being related to 5-year OS, miR-3687 expression was also associated with 5-year OS. The 5-year survival rate of patients with high miR-3687 expression was significantly poorer than that of patients with low expression (40.5\% vs. 58.1\%, $p=0.0487$; Figure 3). Disease-free

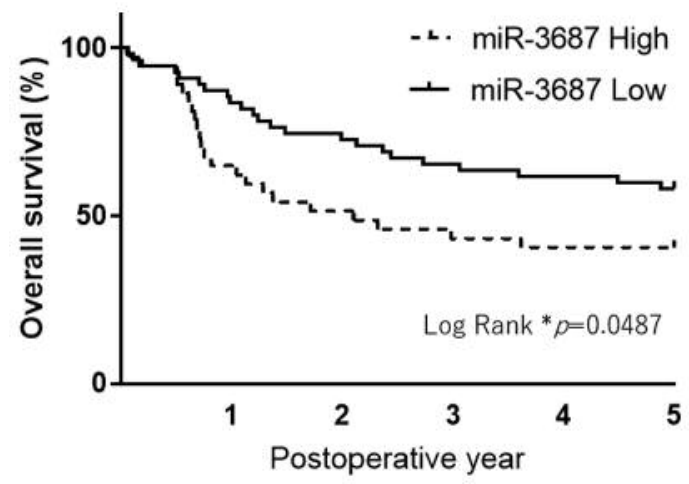

Figure 3. The expression of miR-3687 is associated with overall survival of 92 ESCC patients after curative resection. According to the $q R T-P C R$ data, the expression of miR-3687 was classified into high expression $(n=37)$ and low expression $(n=55)$ by average value. ESCC: Oesophageal squamous cell carcinoma.

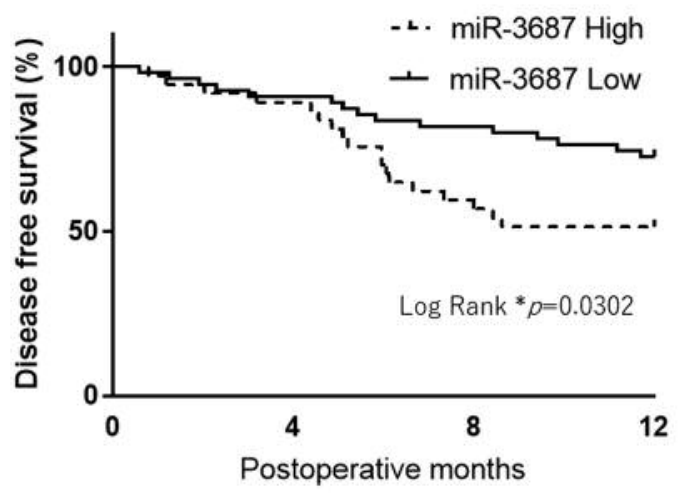

Figure 4. The expression of miR-3687 is associated with disease-free survival of 92 ESCC patients at 1 year after curative resection. Based on the qRT-PCR data, the expression of miR-3687 was classified into high expression $(n=37)$ and low expression $(n=55)$ by average value. ESCC: Oesophageal squamous cell carcinoma.

survival (DFS) was also significantly different between the high and low miR-3687 expression groups at 1-year after surgery $(51.3 \%$ vs. $72.7 \%, p=0.0302$; Figure 4$)$. This shows that high miR-3687 expression was related to poor prognosis and early recurrence.

Association between miR-3687 upregulation and cell migration and invasion. miR-3687 was upregulated in the ESCC cell lines with low miR-3687 expression, namely, KYSE150 and TE14. High miR-3687expression in KYSE150 and TE14 promoted cell migration and invasion, but did not alter proliferation compared to the negative control (Figure 5). Next, miR-3687 was downregulated in ESCC cell lines with high miR-3687 expression, namely, 
A. KYSE30

a. Proliferation

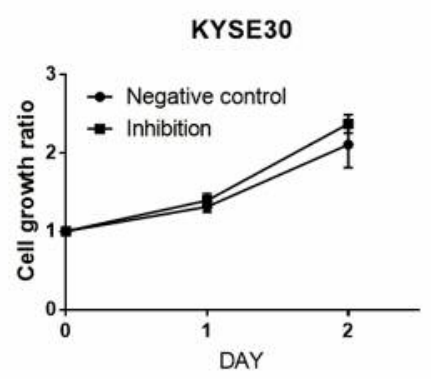

B. TE13

a. Proliferation

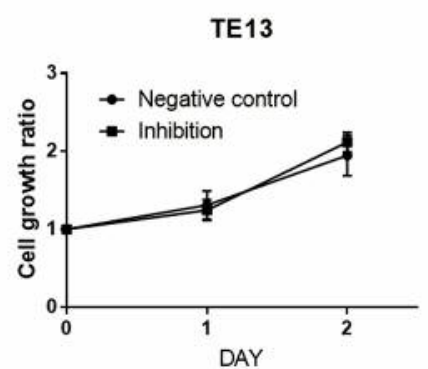

b. Migration and invasion

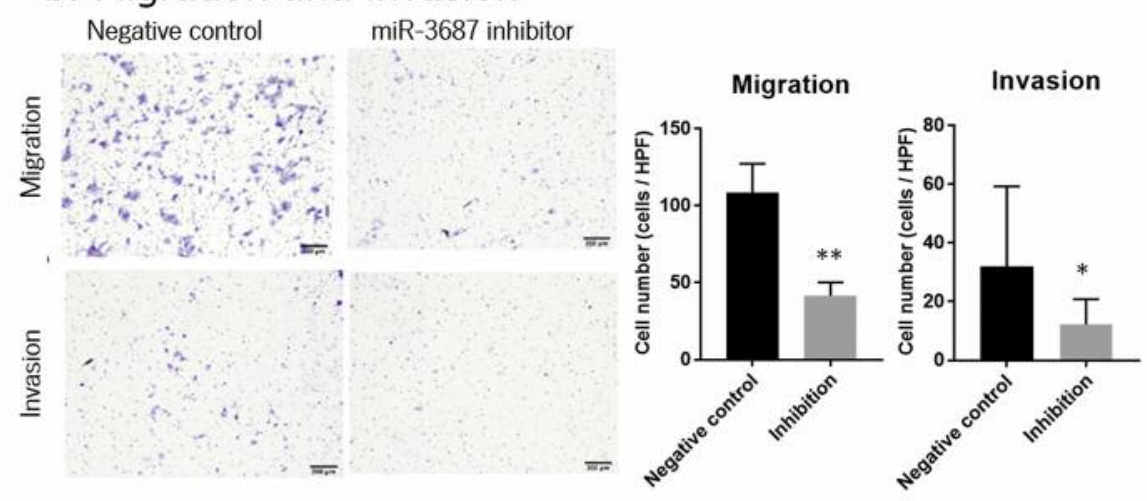

b. Migration and invasion

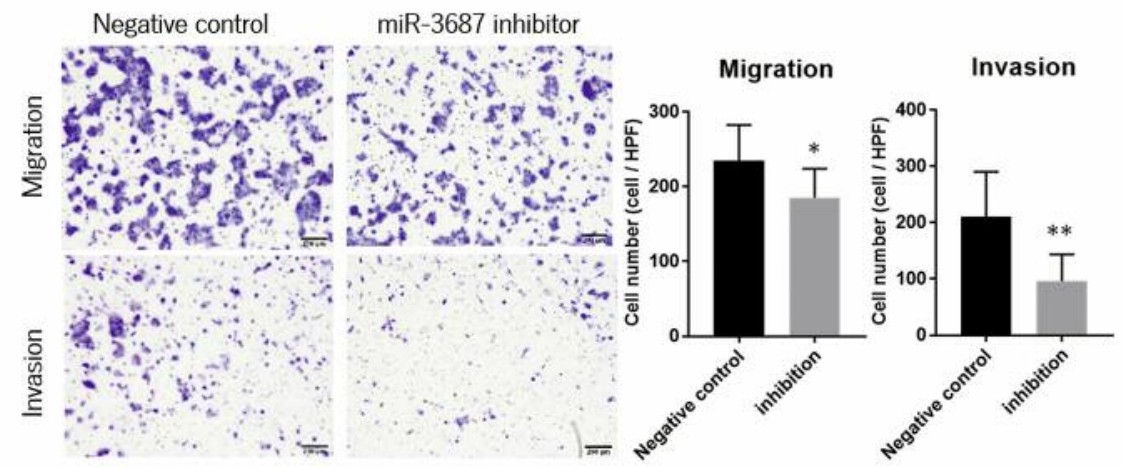

Figure 5. Inhibition of miR-3687 reduced migration and invasion of ESCC cells without altering proliferation. A. KYSE30 B. TE13 (a) Downregulation of miR-3687 did not alter cell proliferation in ESCC cells. (b) The number of migrating or invading cells in the miR-3687 inhibition group was significantly decreased compared to the negative control group. Data are presented as the mean $\pm S D$ of three independent experiments. $* p<0.05,{ }^{* *} p<0.01$. ESCC: Oesophageal squamous cell carcinoma.

KYSE30 and TE13. miR-3687 down-regulation inhibited migration and invasion in KYSE30 and TE13, but did not alter proliferation (Figure 6).

\section{Discussion}

In this study, miR-3687 was related to prognosis and early recurrence of ESCC. Several studies have shown miRNAs to be related to esophageal cancer (22-24). miR-9, miR-25, miR-92a, miR-96, miR-1179, and miR-1290 have been reported as onco miRs related to invasive capability and metastatic potential (25). Target genes of these onco miRs include E-cadherin, reversion-inducing-cysteine-rich protein with kazal motifs, slit homolog 2 (SLIT 2), and suppressors of cancer cell invasion. miR-9, miR-25, and miR 92a targeting the E-cadherin region promotes epithelial-tomesenchymal transition by inhibiting e-cadherin expression and increasing the expression of c-myc, and CD44 in the nucleus. Further, miR-9 and miR-92a are associated with poor prognosis (26-28). Other miRNAs related to prognosis have also been reported (29-31). According to Target scan (32), miR-3687 is associated with DNA binding proteins and ubiquitin related proteins. In addition, miR-3687 target genes which are expected to affect esophageal cancer cells are FGFRL1, MTA2, PGRMC2 and SIRT2. In this study, high miR-3687 expression was related to poor prognosis and a metastatic and invasive ability. miR-3687 was highly expressed in BSCCE tissue. Therefore, cases with high expression of miR-3687 resemble BSCCE with aggressive biological features, resulting in poor prognosis.

It was reported that miR-3687 was highly expressed in conjunctival melanoma; moreover, miR-3687 upregulation was also related to high risk of local recurrence (33). However, no study to date has assessed the impact of 


\section{A. KYSE150}

\section{a. Proliferation}

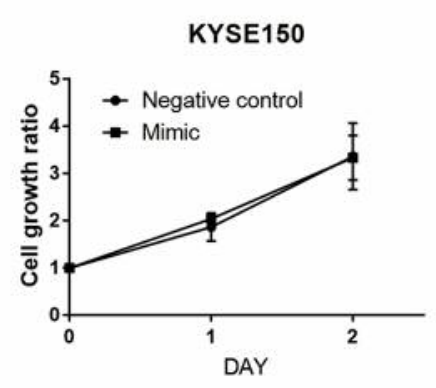

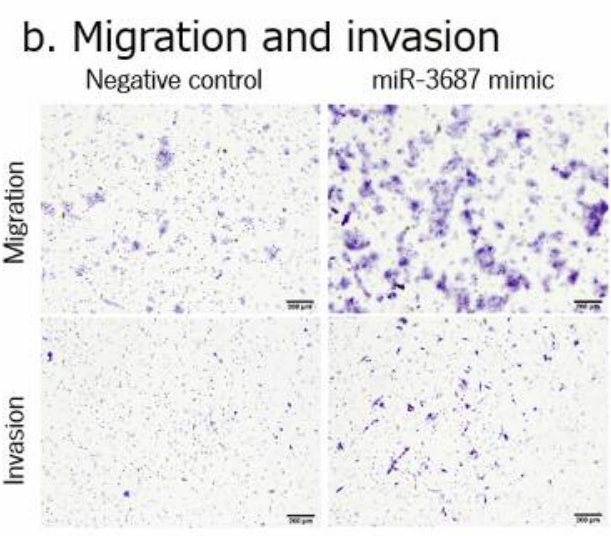
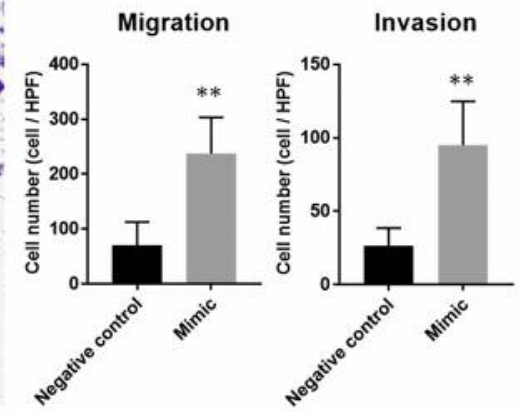

B. TE14

a. Proliferation

TE14

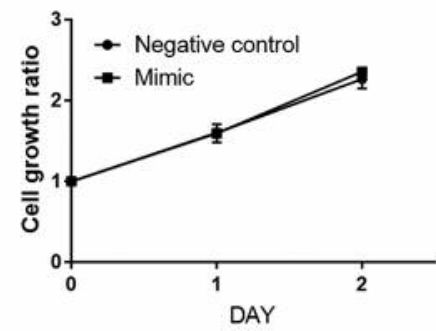

b. Migration and invasion Negative control miR-3687 mimic

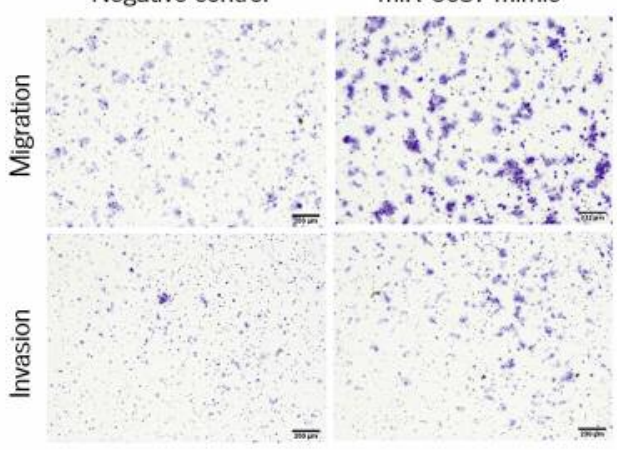

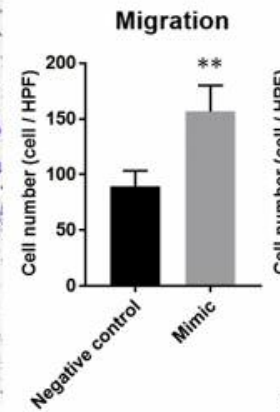

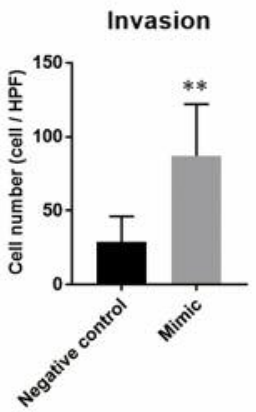

Figure 6. Overexpression of miR-3687 promoted migration and invasion of ESCC cells without altering proliferation. A. KYSE150 B. TE14 (a) Overexpression of miR-3687 didn't alter cell proliferation in ESCC cells. (b) The number of migrating or invading cells in the miR-3687 mimic group was significantly increased compared to the negative control group. Data are presented as the mean $\pm S D$ of three independent experiments. ${ }^{*} p<0.05,{ }^{*} p<0.01$. ESCC: Oesophageal squamous cell carcinoma.

miR-3687 in oesophageal cancer. To the best of our knowledge, this is the first report on miR-3687 in oesophageal cancer.

In general, BSCCE is reported to be more aggressive and have a poorer prognosis than that of typical ESCC (34). Imamhasan et al. reported EGFR and TP53 gene mutations in BSCCE that are associated with poor prognosis (6). Zhang et al. reported that BSCCE had high local recurrence and risk of distant metastasis, and the median relapse-free survival was 10 months (4). Moreover, they reported that BSCCE should be considered an equivalent to ESCC with moderate to poor differentiation.

Our study showed that miR-3687 is highly expressed in BSCCE, and this was related to poor prognosis. Regarding DFS, high miR-3687 expression was related to poor survival rate at 1 year postoperative. Therefore, miR-3687 expression is a potential prognostic marker of early recurrence.
In conclusion, miR-3687 is among the onco-miRs that are related to poor prognosis in ESCC. Thus, miR-3687 is a potential biomarker or treatment target in ESCC. Our findings may have valuable implications for improving the prognosis of BSCCE, but further studies on the specific mechanisms by which miR-3687 affects the metastatic potential and invasive ability in BSCCE are needed.

\section{Conflicts of Interest}

The Authors have no conflicts of interest to disclose regarding this study.

\section{Authors' Contributions}

Kotaro Hagio performed the majority of experiments and wrote the manuscript. Shinji Furuya and Daisuke Ichikawa designed the research and helped to draft the manuscript. All other Authors have contributed to data collection and interpretation, and critically reviewed the manuscript. 


\section{Acknowledgements}

The Authors are grateful to Motoko Inui and Makiko Mishina for their expert technical assistance.

\section{References}

1 World Cancer Report 2014. Stewart BW and Wild CP (eds.) Lyon, France, Int Agency Res Cancer, 2014.

2 Sarbia M, Verreet P, Bittinger F, Dutkowski P, Heep H, Willers $\mathrm{R}$ and Gabbert HE: Basaloid squamous cell carcinoma of the esophagus: Diagnosis and prognosis. Cancer 79(10): 1871-1878, 1997. PMID: 9149011

3 Morice WG and Ferreiro JA: Distinction of basaloid squamous cell carcinoma from adenoid cystic and small cell undifferentiated carcinoma by immunohistochemistry. Hum Pathol 29(6): 609-612, 1998. PMID: 9635682

4 Zhang BH, Cheng GY, Xue Q, Gao SG, Sun KL, Wang YG, Mu JW and He J: Clinical outcomes of basaloid squamous cell carcinoma of the esophagus: A retrospective analysis of 142 cases. Asian Pac J Cancer Prev 14(3): 1889-1894, 2013. PMID: 23679289

5 Lam KY, Law S, Luk JM and Wong J: Oesophageal basaloid squamous cell carcinoma: A unique clinicopathological entity with telomerase activity as a prognostic indicator. J Pathol 195(4): 435-442, 2001. PMID: 11745675, DOI: 10.1002/ path. 984

6 Imamhasan A, Mitomi H, Saito T, Hayashi T, Takahashi M, Kajiyama Y and Yao T: Immunohistochemical and oncogenetic analyses of the esophageal basaloid squamous cell carcinoma in comparison with conventional squamous cell carcinomas. Hum Pathol 43(11): 2012-2023, 2012. PMID: 22607702, DOI: 10.1016/j.humpath.2012.02.010

7 Baba Y, Ishimoto T, Harada K, Kosumi K, Murata A, Miyake K, Hiyoshi Y, Kurashige J, Iwatsuki M, Iwagami S, Miyamoto Y, Sakamoto Y, Yoshida N, Oki E, Iyama K, Watanabe M and Baba $\mathrm{H}$ : Molecular characteristics of basaloid squamous cell carcinoma of the esophagus: Analysis of kras, braf, and pik3ca mutations and line-1 methylation. Ann Surg Oncol 22(11): 3659-3665, 2015. PMID: 25691283, DOI: 10.1245/s10434-015-4445-z

8 Carthew RW and Sontheimer EJ: Origins and mechanisms of mirnas and sirnas. Cell 136(4): 642-655, 2009. PMID: 19239886, DOI: 10.1016/j.cell.2009.01.035

9 Bartel DP: Micrornas: Genomics, biogenesis, mechanism, and function. Cell 116(2): 281-297, 2004. PMID: 14744438

10 Bartel DP: Micrornas: Target recognition and regulatory functions. Cell 136(2): 215-233, 2009. PMID: 19167326, DOI: 10.1016/j.cell.2009.01.002

11 Flynt AS and Lai EC: Biological principles of micrornamediated regulation: Shared themes amid diversity. Nat Rev Genet 9(11): 831-842, 2008. PMID: 18852696, DOI: $10.1038 / \mathrm{nrg} 2455$

12 Esquela-Kerscher A and Slack FJ: Oncomirs - micrornas with a role in cancer. Nat Rev Cancer 6(4): 259-269, 2006. PMID: 16557279, DOI: $10.1038 / \mathrm{nrc} 1840$

13 Derouet MF, Liu G and Darling GE: Mir-145 expression accelerates esophageal adenocarcinoma progression by enhancing cell invasion and anoikis resistance. PLoS One 9(12): e115589, 2014. PMID: 25551563, DOI: 10.1371/ journal.pone.0115589
14 Ma C, Liu Y and He L: Micrornas - powerful repression comes from small rnas. Sci China C Life Sci 52(4): 323-330, 2009. PMID: 19381458, DOI: 10.1007/s11427-009-0056-x

15 Smits M, Nilsson J, Mir SE, van der Stoop PM, Hulleman E, Niers JM, Hamer PCDW, Marquez VE, Cloos J, Krichevsky AM, Noske DP, Tannous BA and Wurdinger T: Mir-101 is down-regulated in glioblastoma resulting in ezh2-induced proliferation, migration, and angiogenesis. Oncotarget 1(8): 710720, 2010. PMID: 21321380, DOI: 10.18632/ oncotarget.205

16 Lin H, Dai T, Xiong H, Zhao X, Chen X, Yu C, Li J, Wang X and Song L: Unregulated mir-96 induces cell proliferation in human breast cancer by downregulating transcriptional factor foxo3a. PLoS One 5(12): e15797, 2010. PMID: 21203424, DOI: 10.1371/journal.pone.0015797

17 Wang CJ, Stratmann J, Zhou ZG and Sun XF: Suppression of microrna-31 increases sensitivity to 5-fu at an early stage, and affects cell migration and invasion in het- 116 colon cancer cells. Bmc Cancer 10, 2010. PMID: 21062447, DOI: 10.1186/14712407-10-616

18 Cummins JM and Velculescu VE: Implications of micro-rna profiling for cancer diagnosis. Oncogene 25(46): 6220-6227, 2006. PMID: 17028602, DOI: 10.1038/sj.onc.1209914

19 Sobin LH, Gospodarowicz MK and Wittekind Ch (eds.): TNM Classification of Malignant Tumours. New Jersey, Wiley Blackwell, 2009.

20 Nishihira T, Hashimoto Y, Katayama M, Mori S and Kuroki T: Molecular and cellular features of esophageal cancer cells. J Cancer Res Clin Oncol 119(8): 441-449, 1993. PMID: 8509434

21 Shimada Y, Imamura M, Wagata T, Yamaguchi $\mathrm{N}$ and Tobe T: Characterization of 21 newly established esophageal cancer cell lines. Cancer 69(2): 277-284, 1992. PMID: 1728357

22 Zhou YW, Zhang H, Duan CJ, Gao Y, Cheng YD, He D, Li R and Zhang CF: Mir-675-5p enhances tumorigenesis and metastasis of esophageal squamous cell carcinoma by targeting reps2. Oncotarget 7(21): 30730-30747, 2016. PMID: 27120794, DOI: 10.18632/oncotarget.8950

23 Li B, Xu WW, Han L, Chan KT, Tsao SW, Lee NPY, Law S, Xu LY, Li EM, Chan KW, Qin YR, Guan XY, He QY and Cheung ALM: Microrna-377 suppresses initiation and progression of esophageal cancer by inhibiting cd133 and vegf. Oncogene 36(28): 3986-4000, 2017. PMID: 28288140, DOI: 10.1038/onc.2017.29

24 Ren LH, Chen WX, Li S, He XY, Zhang ZM, Li M, Cao RS, Hao B, Zhang HJ, Qiu HQ and Shi RH: Microrna-183 promotes proliferation and invasion in oesophageal squamous cell carcinoma by targeting programmed cell death 4 . Br J Cancer 111(10): 20032013, 2014. PMID: 25211657, DOI: 10.1038/bjc.2014.485

25 Harada K, Baba Y, Ishimoto T, Shigaki H, Kosumi K, Yoshida $\mathrm{N}$, Watanabe $\mathrm{M}$ and Baba $\mathrm{H}$ : The role of microrna in esophageal squamous cell carcinoma. J Gastroenterol 51(6): 520-530, 2016. PMID: 26794004, DOI: 10.1007/s00535-016-1161-9

26 Song Y, Li J, Zhu Y, Dai Y, Zeng T, Liu L, Li J, Wang H, Qin Y, Zeng M, Guan XY and Li Y: Microrna-9 promotes tumor metastasis via repressing e-cadherin in esophageal squamous cell carcinoma. Oncotarget 5(22): 11669-11680, 2014. PMID: 25375090, DOI: 10.18632/oncotarget.2581

$27 \mathrm{Xu} X$, Chen Z, Zhao X, Wang J, Ding D, Wang Z, Tan F, Tan X, Zhou F, Sun J, Sun N, Gao Y, Shao K, Li N, Qiu B and He J: Microrna-25 promotes cell migration and invasion in esophageal squamous cell carcinoma. Biochem Biophys Res Commun 421(4): 640-645, 2012. PMID: 22450326, DOI: 10.1016/j.bbrc.2012.03.048 
28 Chen ZL, Zhao XH, Wang JW, Li BZ, Wang Z, Sun J, Tan FW, Ding DP, Xu XH, Zhou F, Tan XG, Hang J, Shi SS, Feng XL and He J: Microrna-92a promotes lymph node metastasis of human esophageal squamous cell carcinoma via e-cadherin. J Biol Chem 286(12): 10725-10734, 2011. PMID: 21148309, DOI: 10.1074/jbc.M110.165654

29 Xu XL, Jiang YH, Feng JG, Su D, Chen PC and Mao WM: Microrna-17, microrna-18a, and microrna-19a are prognostic indicators in esophageal squamous cell carcinoma. Ann Thorac Surg 97(3): 1037-1045, 2014. PMID: 24360091, DOI: 10.1016/j.athoracsur.2013.10.042

30 Liu R, Gu J, Jiang P, Zheng Y, Liu X, Jiang X, Huang E, Xiong $\mathrm{S}$, Xu F, Liu G, Ge D and Chu Y: Dnmt1-microrna126 epigenetic circuit contributes to esophageal squamous cell carcinoma growth via adam9-egfr-akt signaling. Clin Cancer Res 21(4): 854-863, 2015. PMID: 25512445, DOI: 10.1158/10780432.CCR-14-1740

31 Zhao Y, Schetter AJ, Yang GB, Nguyen G, Mathe EA, Li P, Cai H, Yu L, Liu F, Hang D, Yang H, Wang XW, Ke Y and Harris $\mathrm{CC}$ : Microrna and inflammatory gene expression as prognostic marker for overall survival in esophageal squamous cell carcinoma. Int J Cancer 132(12): 2901-2909, 2013. PMID: 23175214, DOI: $10.1002 /$ ijc .27954
32 Agarwal V, Bell GW, Nam JW and Bartel DP: Predicting effective microrna target sites in mammalian mRNAs. Elife 4, 2015. PMID: 26267216, DOI: 10.7554/eLife.05005

33 Larsen AC, Mikkelsen LH, Borup R, Kiss K, Toft PB, von Buchwald C, Coupland SE, Prause JU and Heegaard S: Microrna expression profile in conjunctival melanoma. Invest Ophthalmol Vis Sci 57(10): 4205-4212, 2016. PMID: 27548891, DOI: $10.1167 /$ iovs.16-19862

34 Soriano E, Faure C, Lantuejoul S, Reyt E, Bolla M, Brambilla E and Righini CA: Course and prognosis of basaloid squamous cell carcinoma of the head and neck: A case-control study of 62 patients. Eur J Cancer 44(2): 244-250, 2008. PMID: 18096379, DOI: $10.1016 /$ j.ejca.2007.11.008
Received December 28, 2018

Revised January 16, 2019

Accepted January 17, 2019 